Revista de Literatura, História e Memória

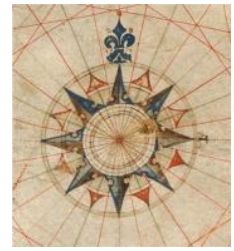

Seção: Pesquisa em Letras no contexto Latino-americano e Literatura, Ensino e Cultura

ISSN 1983-1498

VOL. 17 - Nº 29 - 2021

U N I O E S T E / CA S C A V E L - p. 78-96

\section{HISTÓRIA E MEMÓRIA EM LIMA BARRETO: RAÍZES DA SOCIEDADE BRASILEIRA EM CLARA DOS ANJOS}

History and memory in Lima Barreto: roots of brazilian society in Clara dos Anjos

José Lindomar da Silva ${ }^{1}$

Prometeu, ao Corifeu: Falar-te disso é doloroso para mim, mas calar-me também me causa muitas dores. Ésquilo

RESUMO: Este ensaio é o resultado de observações acerca do romance Clara dos Anjos, de Lima Barreto. A proposta consiste em analisar de que modo se apresenta o preconceito contra o negro, o autoritarismo e os efeitos de uma ideia de modernidade que atingiu a sociedade brasileira entre o final do século XIX e início do século XX. O trabalho mostra as contradições pós-abolição da escravidão na Primeira República, destacando o abandono do negro em uma sociedade que principiava a modernizar-se importando receitas da Europa. O resultado é visto, com nitidez, na Capital da República, um Rio de Janeiro cosmético que enfeita o centro enquanto a população suburbana sofre as mazelas do esquecimento político-econômico. Nesse contexto é que a família dos Anjos, especialmente Clara, sendo mulher, negra e pobre sofre as asperezas da sua condição, numa sociedade preconceituosa, exploradora e autoritária. Assim, o final trágico da personagem central da narrativa designa o destino inevitável de uma classe, um grupo desprivilegiado que ficou à margem do processo de desenvolvimento nacional. Esses aspectos são resgatados pela memória e história literária do referido escritor como forma de resistência.

PALAVRAS-CHAVE: Literatura e sociedade; Preconceito racial; Autoritarismo; Resistência.

ABSTRACT: This essay is the result of observations about the romance Clara dos Anjos, by Lima Barreto. The proposal consists of analyzing how prejudice against blacks, authoritarianism and the effects of an idea of modernity that reached Brazilian society between the end of the 19th century and the beginning of the 20th century are presented. The work shows the post-abolition contradictions of slavery in the First Republic, highlighting the abandonment of blacks in a society that was beginning to modernize by importing recipes from Europe. The result is clearly seen in the Capital of the Republic, a cosmetic Rio de Janeiro that adorns the center while the suburban population suffers the ills of political and economic oblivion. In this context, the family dos Anjos, especially Clara, being a woman, black and poor, suffers the harshness of her condition, in a prejudiced, exploitative and authoritarian society. Thus, the tragic ending of the central character of the narrative designates the inevitable destiny of a class, a disadvantaged group that was left out of the process of national development. These aspects are rescued by the memory and literary history of that writer as a form of resistance.

KEYWORDS: Literature and society; Racial prejudice; Authoritarianism; Resistance.

\footnotetext{
${ }^{1}$ Mestre em Letras pela Universidade do Estado do Rio Grande do Norte (UERN). Professor da Educação Básica do Estado do Rio Grande do Norte (SEEC/RN).
} 


\section{O CONTEXTO, O CRÍTICO E O TEXTO}

A sociedade brasileira foi profundamente marcada por contradições em suas várias mudanças de modelo organizacional e formas de governo. A passagem do século XIX para o século XX é uma data representativa dessa afirmação. Nesse período, verifica-se a transição do Segundo Reinado para a República. É interessante observar que a República brasileira nasceu um ano após a formalização da abolição da escravidão com a criação da Lei Áurea, um dispositivo legal, de apenas dois parágrafos, assinado pela Princesa Isabel em 1888. O fato é que a nova forma de governo inflamou os ânimos da população, que não sabia bem do que se tratava toda aquela propaganda militarizada. Aristides Lobo, um dos propagandistas da República, mostrou-se extremamente desapontado com o novo regime, pois, segundo ele mesmo comentou, "o povo, que pelo ideário republicano deveria ter sido protagonista dos acontecimentos, assistira a tudo bestializado, sem compreender o que se passava, julgando ver talvez uma parada militar" (CARVALHO, 1987, p. 9). Assim, as mudanças sociais e políticas, que tanto anseio provocavam no povo, pareciam esbarrar em uma estrutura social que aumentou sua base de dominação e exclusão popular.

O centro brasileiro na Primeira República era a cidade do Rio de Janeiro. As principais mudanças sociais, econômicas e políticas partiam das decisões tomadas naquele espaço. Foi nesse ponto que surgiu um novo problema, pois no Brasil começava a florescer a vontade de implantar um ideário de modernização, algo que estivesse de acordo com os padrões europeus. Na Capital da República, por exemplo, era possível perceber que o antigo poder rural e suas influências cediam lugar aos novos instrumentos e signos da modernidade, que se notava nas indústrias, na arquitetura de casas e ruas e na formação de uma classe intelectual $\grave{a}$ la français, que se alinha ao espírito da Belle Époque. Com isso, o centro do Rio de Janeiro passou por um processo de apagamento de suas origens coloniais e escravista. Os negros, recém-libertos, juntamente com a classe mais pobre da população, foram expulsos para as margens da sociedade, ocupando os subúrbios.

Ao lado de todos esses processos, nasceu no Rio de Janeiro, em 1881, o escritor Afonso Henriques de Lima Barreto. Em A vida de Lima Barreto, um estudo fundamental para entender a vida e a obra desse autor, Barbosa (2017) destaca que já na infância Lima Barreto sofreu o primeiro golpe, a morte da mãe, Amália. Nesse período passou a sentir-se vulnerável. Contudo, viu com alegria, junto ao pai, os festejos da abolição da escravidão, ocorridos no dia de seu aniversário de 7 anos. Ainda muito jovem, acompanhou com certo desgosto o 15 de novembro, talvez desgosto não pela República em si, mas por quem/como a proclamou. 
Estudou, contra sua vontade, no Liceu Popular Niteroiense, pois não gostava da prisão do internato nem dos métodos de ensino. Aos 12 anos já possuía uma visão crítica do regime florianista e das catástrofes relacionadas ao governo, como: execuções, fuzilamentos, encarceramentos e homicídios. A partir de então, começou a perceber as injustiças da vida, as manifestações de violência sem motivos, o sacrifício dos humildes e a indiferença dos poderosos. Sentiu esse emaranhado de incoerências da vida com grande perplexidade. $\mathrm{Na}$ adolescência, sempre mergulhado em livros, manifestou inclinação para os estudos filosóficos, a literatura ainda não o havia seduzido. Na Escola Politécnica teve, com mais nitidez, outra grande percepção da realidade social, a diferença de classes e o preconceito racial. Viu como os alunos ricos e brancos tinham tudo à disposição, sem preocupações de ordem material; em contraste com os alunos pobres e pretos, com possibilidades reduzidas em todas as instâncias. Sofreu outro golpe quando o seu pai, João Henriques, ficou louco. A partir disso, Lima Barreto passou a arcar com todas as responsabilidades da numerosa família, assim como com os problemas advindos desse fato e de sua condição social precária. Precisou abandonar a Escola Politécnica e passou a acumular desgostos. Foi provavelmente assim que iniciou sua vida no álcool.

Lima Barreto trabalhou em jornais e se estabilizou, pela necessidade, como funcionário público, ganhando muito pouco como amanuense na Secretaria de Guerra. Passou a viver no subúrbio, longe das bibliotecas e cafés, dos encontros com artistas, escritores e jornalistas. Aceitou tudo isso com relutância, cheio de responsabilidades com a família e metido em seu quarto, agora dedicado em seu empenho de fazer da literatura o grito dos excluídos. Devido aos descompassos de uma vida sofrida, o álcool e os problemas familiares, chegou a ser internado em um hospício por duas vezes, mas seu triste fim se deu no dia $1^{\circ}$ de novembro de 1922, aos 41 anos, em sua casa no bairro de Todos os Santos, no Rio de Janeiro, quando foi tomado por um colapso cardíaco e veio a falecer.

Lima Barreto possui uma vasta produção literária que contempla, entre outros escritos, romances, contos, crônicas e sátiras. Sua curta carreira, interrompida precocemente por sua morte, aos 41 anos, teve como missão contar, como poucos, a história do negro no Brasil e os demais dissabores de uma sociedade autoritária, preconceituosa e elitista. Tratou esses problemas com tamanha proximidade que recebeu fortes críticas quanto à natureza autobiográfica de suas obras, que foram injustamente consideradas cheias do social e da vida do autor, mas carente quanto ao fator da arte. Entre os principais críticos da questão autobiográfica em Lima Barreto estão José Veríssimo, Sérgio Buarque de Holanda, Alfredo Bosi e Antonio Candido. Contudo, assumindo que Lima Barreto muitas vezes encarou a 
literatura como uma missão, pautada na análise da sociedade e da condição humana, não se pode esquecer que o fez por "sua deliberada opção por uma literatura militante, na qual pudesse tratar com 'absoluta sinceridade' os problemas que afligiam a sociedade de seu tempo, os quais o afetavam diretamente" (FREIRE, 2014, p. 87). Ademais, para não incorrer em certos discursos que feriram intencionalmente os valores éticos da obra barretiana, é preciso destacar que toda ética pressupõe uma estética, ou como pontuou Bosi (2002), a resistência se dá como tema e como processo inerente à escrita. É fundamental levar isso em conta para compreender a essência da obra de Lima Barreto e para entender o que há por trás da crítica que o associou por tanto tempo à figura do bêbado e do louco.

Entre as produções romanescas de Lima Barreto, destaca-se Clara dos Anjos. Esse romance começou a ser esboçado, como se percebe no Diário íntimo (BARRETO, 1956), em 1904, sendo escrito dois capítulos e mais dois ou três planejados. Em 1920, Clara dos Anjos surgiu mais uma vez, agora em forma de conto, na coletânea Histórias e sonhos, contos escolhidos pelo escritor e publicados pela editora de Francisco Schettino. Sentindo-se bastante debilitado e pressentindo o seu destino irremediável, em apenas dois nesses escreveu finalmente o romance Clara dos Anjos, reduzindo bastante o projeto inicial. A obra final foi concluída em 1922, mas só foi publicada postumamente, em 1948. O que restou da primeira versão foi uma página descrevendo o Rio de Janeiro, mais tarde aproveitada em "O passador", um dos capítulos de Vida e Morte de M. J. Gonzaga de Sá (BARBOSA, 2017).

Do conto para o romance notam-se algumas diferenças. O personagem Júlio Costa cede lugar a Cassi Jones, este de características "abomináveis" ainda mais exaltadas, um verdadeiro "patife costumaz". Clara do conto parece ter mais iniciativa que Clara de "natureza amorfa, pastosa", do romance póstumo. No conto, Clara finaliza a narrativa com a frase "Mamãe, eu não sou nada nesta vida" (BARRETO, 1920, p. 153). No romance, a protagonista declara "Nós não somos nada nesta vida" (BARRETO, 2011, p. 144), de certo modo, agora no plural, enxergando não apenas a sua inferioridade, mas a de sua classe. Apesar das particularidades entre as obras, a ideia central permanece a mesma: contar a triste história de uma mulher negra e pobre do subúrbio do Rio de Janeiro, vítima de injustiças, de uma sociedade preconceituosa, indefesa diante de defloradores brancos e de condição social superior. Notadamente, a obra de Lima Barreto percorre outros temas que foram transpostos em suas obras com o rigor da verdade e expressiva lucidez. Esse é o compromisso do autor de Clara dos Anjos ao representar, por meio da história e memória literária, a sociedade brasileira do seu tempo. 


\section{O REFÚGIO DOS INFELIZES}

Um traço marcante em Clara dos Anjos é a descrição do espaço, tanto físico quanto social. A primeira mostra de ambientação das personagens é feita sobre Joaquim dos Anjos. Desgostoso com a existência medíocre em Diamantina, sua cidade natal em Minas Gerais, muda-se para o Rio de Janeiro, com a ajuda do geólogo John Herbert Brown, que fora seu patrão na cidade mineira. Chegando ao Rio de Janeiro, seus planos de ascensão social foram logo ceifados quando procurou emprego em um escritório de um grande advogado, e este lhe adiantou: "Não te darei coisa que valha a pena" (BARRETO, 2011, p. 16). Após o falecimento da mãe, em Diamantina, recebeu alguns bens como herança e os vendeu em seguida. Pensou em comprar uma pequena casa no subúrbio, mesmo não tendo recebido o dinheiro da venda dos bens herdados. Depois de anos conseguiu se estabilizar, e agora estando "em plena posse do seu 'buraco', como ele chamava a sua humilde casucha" (BARRETO, 2011, p. 17). O narrador apresenta a casa de Joaquim dos Anjos com toda a sua simplicidade estrutural, mas o pior era a rua em que se situava, pois "quando chovia, encharcava e ficava que nem um pântano" (BARRETO, 2011, p. 17). Joaquim morava em uma rua sossegada, onde as construções eram feitas ao gosto dos antigos subúrbios. Havia ainda a exploração aos que moravam em outras casas relativamente recentes, "repletas de uns certos requififes e galanteios modernos, para lhes encobrir a estreiteza dos cômodos e justificar o exagero dos aluguéis" (BARRETO, 2011 p. 18). As transformações do espaço público do Rio de Janeiro, no início do século XX, estavam ligadas, conforme Sevcenko (1995), a quatro ideias principais: I) a condenação dos hábitos e costumes ligados pela memória à sociedade tradicional; II) a negação de todos e qualquer elemento da cultura popular que pudesse macular a imagem civilizada da sociedade dominante; III) uma política rigorosa de expulsão dos grupos populares da área central da cidade, que será praticamente isolada para o desfrute exclusivo das camadas aburguesadas; e IV) um cosmopolitismo agressivo, profundamente identificado com a vida parisiense. Dessa forma, para se adequar ao padrão europeu de modernidade, era necessária uma espécie de apagamento das marcas da tradição colonial e exploração escravista que envergonhavam a nova estrutura urbana e social.

Representativa também é a descrição de um ponto de encontro bastante popular do subúrbio, o armazém do Seu Nascimento. O seu ambiente de trabalho era bastante chamativo, pois "a sua casa de negócio ficava num lugar pitoresco, calmo, pouco transitado" (BARRETO, 2011, p. 60). Ele gostava de pessoas que iam ao seu recinto conversar e ler jornais, hábitos característicos do interior. Além disso, sua venda tinha antigos tamboretes de 
abrir e fechar, típicos dos "armazéns roceiros". O próprio Seu Nascimento parece compor a memória histórica da cidade, um ser propício para o subúrbio, já que "era um homem alto, claro, um tanto obeso, tipo do antigo agricultor patriarcal, das nossas velhas fazendas" (BARRETO, 2011, p. 64). A sua fisionomia se une à imagem do lugar que ocupa.

O trajeto que Cassi fez até a casa de Lafões, para buscar informações sobre o possível responsável por escancarar seu mau-caratismo à família do carteiro Joaquim dos Anjos, merece particular atenção. Para chegar à residência de Lafões, Cassi tomou o bonde na Piedade, passou por ruas despovoadas até a do Engenho de Dentro. O trajeto é descrito como pitoresco, não apenas pelos restos de capoeira grossa que ainda resistiam, mas também "pelas casas roceiras de varanda e pequenas janelas de outros tempos" (BARRETO, 2011, p. 68). Certamente era um caminho de "tropas". Os desnivelamentos, atoleiros e outra sorte de obstáculos transformavam o caminho do bonde em uma espécie de "montanha-russa", "com a lembrança, de um lado e outro, do espetáculo do que seriam ou do que são os caminhos do nosso interior" (BARRETO, 2011, p. 68). Quando o bonde aproximava-se de algum lugar povoado, fazendo seu barulho tradicional, ou zunindo o seu apito, "aqueles homens, vivendo tão perto da terra e da natureza espontânea, não deixavam de se assustar e tomar precauções, para sua segurança e dos seus pacientes animalejos" (BARRETO, 2011, p. 68-69). Após todo o esforço feito, finalmente Cassi chegou à casa de Lafões, uma habitação pequena, mas bem tratada e limpa. Com isso, vemos que, ao lado do Rio de Janeiro que se modernizava, o narrador mostra o Rio não oficial, com marcas da tradição histórica.

A importância que ganha o subúrbio, como espaço de representação social, faz com que o narrador de Clara dos Anjos considere necessário realizar uma descrição precisa de sua extensão. Por ele sabemos que "o subúrbio propriamente dito é uma longa faixa de terra que se alonga, desde o Rocha ou São Francisco Xavier, até Sapopemba, tendo para eixo a linha férrea da Central" (BARRETO, 2011, p. 78). Devido à geografia do lugar, para os lados o subúrbio não se aprofunda muito, por conta das colinas e montanhas. Mesmo assim, parece crescer na vertical, formando "azinhagas e trilhos, charnecas e morrotes" (BARRETO, 2011, p. 78). A dificuldade de acesso a esses lugares é notável, o que não impede que se construa um ou mais barracões sob certas elevações. O modo de fixar moradia parece ser mais pela necessidade que pela vontade, tendo em vista que "há casas, casinhas, casebres, barracões, choças, por toda a parte onde se possa fincar quatro estacas de pau e uni-las por paredes duvidosas" (BARRETO, 2011, p. 78). Para essas construções qualquer material serve: "são latas de fósforos distendidas, telhas velhas, folhas de zinco, e, para as nervuras das paredes de taipa, o bambu, que não é barato" (BARRETO, 2011, p. 78). As condições a que as pessoas 
que ocupam esses espaços estão expostas revelam a pobreza em que se encontram, bem como a vulnerabilidade a todo tipo de mazela. Por isso, "constitui o espaço um elemento da máxima importância e também dos mais interessantes no universo ficcional de Lima Barreto" (LINS, 1976, p. 60). Não só o espaço físico, mas também o social.

Em Clara dos Anjos os indivíduos suburbanos estão jogados à própria sorte e, na maioria das vezes, sequer têm consciência de seu estado de degradação. Por esse motivo, "a gente pobre é difícil de se suportar mutuamente; por qualquer ninharia, encontrando ponto de honra, brigando, especialmente as mulheres" (BARRETO, 2011, p. 79). Ironicamente, os desentendimentos e problemas estruturais não parecem ser culpa do esquecimento político, do abandono social, mas, como querem os governantes, dos próprios indivíduos que não são capazes de apresentar civilidade. É nesse espaço e sob essas condições que vive grande parte da população da cidade, "a cuja existência o governo fecha os olhos, embora lhe cobre atrozes impostos, empregados em obras inúteis e suntuárias noutros pontos do Rio de Janeiro" (BARRETO, 2011, p. 79). Mesmo assim, todos os dias é grande o movimento de pessoas que saem dos mais variados lugares para a estação mais próxima. São pequenos empregados, operários, militares, funcionários públicos, entre outros. Por esses motivos, "o subúrbio é o refúgio dos infelizes. Os que perderam o emprego, as fortunas; os que faliram nos negócios, enfim, todos os que perderam a sua situação normal vão se aninhar lá" (BARRETO, 2011, p. 81). Em síntese, o subúrbio é o lugar dos que não têm espaço em uma cidade que principia a enfeitar-se, a modernizar-se e, por isso, jogar às margens aqueles que representam uma lembrança triste de suas origens. Nesse sentido, o espaço está ligado à condição social.

Ao lado do espaço degradante do subúrbio, há outro Rio de Janeiro, com "algumas estradas construídas pela Prefeitura, que se podem considerar como tal; mas, logo que se chega ao Estado, tudo falta, nem nada há embrionário" (BARRETO, 2011, p. 81). Esta é a distinção entre o centro e a periferia, o espaço dos excluídos contraposto ao dos privilegiados.

O próprio Cassi Jones não gostou do centro da cidade, e demonstrou isso quando precisou ir à Caixa Econômica depositar certa quantia de dinheiro, obtida na venda de seus galos de briga: "Implicava com aqueles elegantes que se postavam nas esquinas e nas calçadas. Achava-os ridículos, exibindo luxo de bengalas, anéis e pulseiras de relógio" (BARRETO, 2011, p. 121). O desgosto pelo outro lado do Rio pareceu vir do fato desse espaço trazer à tona sua verdadeira face, um indivíduo inferior, ignorante, grosseiro, sem educação e, por isso, "secretamente, tinha um respeito pela cidade, respeito de suburbano genuíno que ele era, mal-educado, bronco e analfabeto" (BARRETO, 2011, p. 122). Aqui se descreve o suburbano genuíno, um tipo específico de indivíduo, mal educado, bronco e 
analfabeto. São características que depreciam a figura do sujeito tido como insignificante, contraposto aos indivíduos civilizados do centro da cidade. O subúrbio dava a esse tipo de gente um status que não possuía, "no subúrbio, enfim, ele tinha personalidade, era bem Cassi Jones de Azevedo; mas, ali, sobretudo do Campo de Sant'Ana para baixo, o que era ele? Não era nada" (BARRETO, 2011, p. 122). Talvez não haja personagem melhor para mostrar a oposição centro versus periferia que Cassi Jones, fosse por admiração, inveja ou outro sentimento, o fato é que, transitando pelas ruas do centro da cidade, não deixou de observar as lojas de roupas feitas, as joias nas vitrines, a livraria com muitos livros de alto a baixo, livros que para ele eram de quantidade desnecessária e possivelmente só servia para "fazer doidos".

Mesmo na cidade, Cassi conheceu mais um refúgio para os excluídos, eram becos escuros formados por sobrados mal cuidados, pouco transitados e com roupas penduradas no varal. Tudo isso formava "uma estranha cidade à parte, onde se iam refugiar homens e mulheres que haviam caído na mais baixa degradação e jaziam no último degrau da sociedade" (BARRETO, 2011, p. 124). Os homens que ocupavam aquele espaço possuíam certa posição social, mas as mulheres estavam jogadas no mais elevado nível de degradação, constatado em sua aparência: "Havia negras, brancas, mulatas, caboclas, todas niveladas pelo mesmo relaxamento e pelo seu triste fado" (BARRETO, 2011, p. 124). Desse modo, em Clara dos Anjos, "o espaço social, entretanto, não se confunde com a atmosfera" (LINS, 1976, p. 75, grifos do autor). Assim, o espaço assume a configuração de unidade representacional de grande importância para a compreensão da narrativa e do contexto da época, em que:

os negros e mulatos ficaram à margem ou se viram excluídos da prosperidade geral, bem como de seus proventos políticos, porque não tinham condições para entrar nesse jogo e sustentar as suas regras. Em consequência [sic], viveram dentro da cidade, mas não progrediram com ela e através dela (FERNANDES, 2008, p. 120, grifos do autor).

Foi esse esquecimento político-econômico que fez principalmente os negros ocuparem o subúrbio. O narrador faz questão de apresentar diferentes tipos de subúrbios e os motivos que os tornam distintos. A família de Cassi Jones, por exemplo, residia num subúrbio considerado como elegante, "porque lá também há estas distinções. Certas estações são assim consideradas, e certas partes de determinadas estações gozam, às vezes, dessa consideração, embora em si não o sejam" (BARRETO, 2011, p. 141). É comum que se encontre nos subúrbios, ao lado de uma rua abandonada, coberta pelo matagal, outra de "ar urbano", cuidada, limpa, calçada de paralelepípedos, como a da família de Cassi. A explicação para 
essas contradições são dadas pelos historiadores locais: "é porque nela, há anos, morou o deputado tal ou o ministro sicrano ou o intendente fulano" (BARRETO, 2011, p. 141). Os subúrbios possuíam características de acordo com a importância que mereciam. Notadamente, a atenção a um subúrbio onde morava um deputado, ministro ou intendente era diferente da atenção dada a um subúrbio habitado por gente pobre e negra. A representação do espaço em Clara dos Anjos, com a descrição de detalhes feita por Lima Barreto, é uma denúncia ao total abandono que marca os "infelizes" que foram obrigados a se refugiar naquele ambiente degradante. O espaço é também condutor da memória histórica, como contraponto entre a promessa infrutífera e a realidade na mudança de regime com protagonismo elitista. Nesse sentido, como já foi postulado por Bosi (2002), a literatura resiste à mentira, não é apenas o lugar da fantasia, mas, nessa perspectiva, pode ser o lugar da verdade mais exigente.

\section{SOCIEDADE DE APARÊNCIAS}

Para o sociólogo moderno, a arte é social tanto por depender da ação de fatores do meio, representados na obra de modo variado, quanto pelo fato de exercer sobre os indivíduos um efeito prático, que possibilitaria uma mudança no seu modo de ser e ver o mundo, ou pelo menos, reforçando sentimentos e valores que estes indivíduos já possuem (CANDIDO, 2006)

Um traço que define a personalidade de Lima Barreto é sua aversão ao comportamento imoral e antiético no uso do poder político, o paternalismo; ao pedantismo intelectual; às injustiças sociais; ao autoritarismo baseado em hierarquias sociais; enfim, a tudo que representa uma sociedade de aparências. Afinal de contas, "o seu nacionalismo (como o seu internacionalismo) era o dos pobres. As relações entre cultura e nação formulam-se em Lima Barreto sob um ângulo novo e, com certeza, progressista" (BOSI, 1992, p. 268). É com esse tom que apresentará a verdadeira face da sociedade brasileira. A começar pela questão política, quando o poder público é utilizado para atender a interesses particulares. Uma passagem que marca essa relação pode ser vista quando Meneses está conversando com um porteiro sobre a possibilidade de conseguir trabalho com a ajuda de um político:

—Ah! Então o Senhor é engenheiro?

- Sim, mas mecânico. Trabalho, porém, com o nível e com o trânsito.

-Agora, deve haver muito trabalho para engenheiro; vão-se fazer grandes obras... Aproveite, doutor!

- Trago aqui uma carta para o Deputado Sepúlveda. Tem influência?

- Muita! É o pensamento da política mineira... Não lhe deixe a aba do fraque, doutor! (BARRETO, 2011, p. 86). 
O Deputado parecia ter bastante influência, pois Meneses foi admitido no dia seguinte, após o encontro com o político. Deve ser levado em conta que Meneses levou uma carta de recomendação do Coronel Carvalho, seu protetor, e que o senhor Sepúlveda lhe tratou muito bem, perguntando pela gente "grada" do lugar onde Meneses morava, e enviou, por ele, outra carta para o chefe da construção da avenida em atitude costumeiramente paternalista. Sobre essa questão, Holanda (1995, p. 146) destaca que:

a escolha dos homens que irão exercer funções públicas faz-se de acordo com a confiança pessoal que mereçam os candidatos, e muito menos de acordo com suas capacidades próprias. Falta a tudo a ordenação impessoal que caracteriza o Estado burocrático.

Essa é uma característica dos círculos fechados das elites brasileiras, que se manifesta ao longo da história até a atualidade. A aversão ao comportamento político sobre a sociedade é sintetizada pelo poeta Leonardo Flores: “- Como é belo o céu! Lá não haverá por certo ministros, nem congresso, nem presidentes... Que bom será!” (BARRETO, 2011, p. 134). Contemplar a beleza do céu, desvinculada de qualquer presença política, juntamente com a expressão enfática de que será bom chegar ao paraíso, mostra de forma irônica o desprezo por essa classe de indivíduos que não enxerga além de seus interesses pessoais.

Como grande observador das contradições do seu tempo, Lima Barreto criticou o autoritarismo de algumas classes sociais. Nesse sentido, é sintomático o bovarismo de Dona Salustiana, mãe de Cassi Jones de Azevedo: “o Jones é que ninguém sabia onde ele o fora buscar, mas usava-o, desde os vinte e um anos, talvez, conforme explicavam alguns, por achar bonito o apelido inglês" (BARRETO, 2011, p. 25). Alguns detalhes são curiosos nesse trecho. Pela voz do narrador, sabe-se que o Jones veio não somente pela beleza inglesa, mas pelas crises de vaidade de Dona Salustiana, que dizia ser descendente de um fantástico Lord Jones, que fora cônsul da Inglaterra, em Santa Catarina. Cassi não foi batizado com o Jones, visto que passou a usá-lo somente aos vinte e um anos. Salustiana Baeta de Azevedo vivia no subúrbio, mas não se enxergava como suburbana, pois via em suas supostas origens motivo para sentir-se superior.

Intenção semelhante verifica-se em Os Bruzundangas. Ricardo Silva da Conceição, como era conhecido desde sempre onde morava, ficou rico de forma repentina, metendo-se com especulações financeiras. Após a ascensão social, não sendo doutor, decide mudar de nome para parecer mais importante, assim, converte-se em Ricardo Silva de la Concepción, 
que associa ao sobrenome de um príncipe espanhol. Nesses casos, é possível perceber "os rasgos de impaciência de Lima ao surpreender, a cada passo, o fetiche do estrangeirismo que medusava o Rio do seu tempo" (BOSI, 1992, p. 269-270). Esse traço está presente em grande parte da obra de Lima Barreto.

Em determinado momento, quando precisou ir ao centro do Rio, Cassi enxergou a si mesmo, as suas limitações e fraquezas: "Na 'cidade', como se diz, ele percebia toda a sua inferioridade de inteligência, de educação; a sua rusticidade, diante daqueles rapazes a conversar sobre coisas de que ele não entendia e a trocar pilhérias" (BARRETO, 2011, p. 123). Na cidade Cassi não era nada, ou era ele mesmo. O seu bovarismo evaporava-se em meio à indiferença das outras pessoas elegantes, cultas, de costumes que julgava terem sido copiados de lugares que ele não sabia. De outro modo, Dona Salustiana se esforçava por manter as aparências, inclusive quando Cassi decide viajar para o Mato Grosso, onde supostamente seria chefe de turma em uma construção de estrada de ferro.

—Minhas filhas, vocês não sabem que desgraça para a família, Cassi...

-Que houve? - assustou-se Catarina.

- Cassi está doido e quer nos envergonhar a todos nós, o meu avô que foi cônsul da Inglaterra... Ah! Se ele ressuscitasse — que vexame não passaria! - Que é que Cassi vai fazer? - fez Irene com calma.

- Vai ser trabalhador de enxada, numa estrada de ferro de Mato Grosso (BARRETO, 2011, p. 121).

Dona Salustiana sabia da incapacidade intelectual do filho para ocupar um posto de excelência na construção da estrada de ferro. Ser trabalhador de enxada representava uma humilhação para a família, que tinha no suposto Lord Jones, que fora cônsul da Inglaterra, motivo de orgulho e representação social. Ela julgava-se superior às pessoas da sua vizinhança, sentia-se uma verdadeira dama. Seu orgulho estava centrado em duas fontes: o irmão médico do Exército, com o posto de capitão, representava o orgulho da posição social; ter frequentado o Colégio das Irmãs de Caridade representava o orgulho moral. Certa vez, Manoel Azevedo, marido de Salustiana, propôs que pusesse Cassi para aprender um ofício. Do alto da sua falsa nobreza, a esposa retrucou: "Meu filho aprender um ofício, ser operário! Qual! Ele é sobrinho de um doutor e neto de um homem que prestou muitos serviços ao país" (BARRETO, 2011, p. 37). Era essa referência familiar que fazia Salustiana usar seu autoritarismo de pseudoelite para se impor, quando necessário, em defesa do filho. Em determinadas situações é como se ela dissesse, implicitamente: sabe com quem está falando? O uso dessa expressão, velada ou não, “implica sempre uma separação radical e autoritária de 
duas posições sociais real ou teoricamente diferenciadas" (DAMATTA, 1997, p. 181). É também uma expressão que demonstra os mais variados tipos de preconceitos, arraigados nas raízes mais profundas da sociedade.

A principal vítima do autoritarismo de Salustiana, encorajado pela diferença de condição social e de cor, foi Clara. Após saber que estava grávida de Cassi, a jovem mulata foi com a mãe e dona Margarida até a casa da família Azevedo. Quando Dona Margarida apresenta a situação, Salustiana, como era de costume, pergunta o que querem que ela faça e obtém, inesperadamente, a resposta de Clara:

- Que se case comigo.

Dona Salustiana ficou lívida; a intervenção da mulatinha a exasperou. Olhou-a cheia de malvadez e indignação, demorando o olhar propositadamente. Por fim, expectorou:

-Que é que você diz, sua negra?

$[\ldots]$

—Casado com gente dessa laia... Qual!... Que diria meu avô, Lord Jones, que foi cônsul da Inglaterra em Santa Catarina - que diria ele, se visse tal vergonha? Qual! (BARRETO, 2011, p. 142-143).

Para humilhar Clara, mais uma vez, Dona Salustiana recorre à representação do avô, o suposto Lord Jones. Sabe-se ainda que ela se envaidece por ter um irmão médico no exército. Desse modo, o sabe com quem está falando? "parece mesmo permitir a identificação por meio da projeção social" (DAMATTA, 1997, p. 192). Dona Salustiana não era uma figura importante no subúrbio, não tinha grande riqueza ou outro atributo que pudesse confirmar sua superioridade, mas usava da importância dos supostos familiares para projetar sobre si a imposição, o autoritarismo, sobre os outros. Portanto “o 'sabe com quem está falando' é, então, antigo. Já Lima Barreto [...] revela a sofreguidão de uso dos títulos e formas hierarquizantes [...] em nome de uma relação pessoal importante" (DAMATTA, 1997, p. 192). É da relação familiar que surge a falsa grandeza de Salustiana. É no seio dessa problemática que emerge a crítica de Lima Barreto a uma sociedade de aparências.

Lima Barreto não deixa escapar também os falsos intelectuais, figuras que se intitulam grandes doutores, como é o caso de Praxedes Maria dos Santos, que gostava de ser tratado por doutor Praxedes: "A monstruosidade de sua cabeça o pusera a perder. Por tê-la assim, julgouse uma inteligência, um grande advogado, e pôs a freqüentar [sic] cartórios, servindo de testemunha, quando era preciso, indo comprar estampilhas, etc., etc.” (BARRETO, 2011, p. 49). A ridicularização do título atribuído a si próprio por Praxedes é associada, pelo narrador, à monstruosidade da sua cabeça, que o fez confundir tamanho com inteligência. $\mathrm{O}$ escárnio de 
Praxedes continuou quando ele tentou recitar um poema de título "A lágrima", e esboçou um verdadeiro malabarismo corporal para dramatizar com os mais variados gestos o recital; ou quando quis explicar a Joaquim, Lafões e Marramaque o que era um habeas corpus preventivo: "-Exemplifico - dizia o doutor Praxedes, erguendo a mão direita catedraticamente, com o indicador apontado para o teto. - É uma medida perfeitamente jurídica de profilática, porque...” (BARRETO, 2011, p. 51). É recorrente a crítica a esse tipo de figura na obra de Lima Barreto. Em Os Bruzundangas, há o caso de Carlos Chavantes, que partiu de Bruzundanga para o estrangeiro com este nome, chegando ao seu destino se encontrou com algumas senhoras em um café dançante, estas passaram a tratá-lo como marquês. Ele mesmo não acreditou, até que uma delas pediu-lhe 20 contos e em 20 minutos construiu-lhe a árvore genealógica que lhe deu o título de Marquês de Libreville. Ainda em Os Bruzundangas, o narrador afirma que a improvisação de títulos se dá pelas formas mais estranhas. Possivelmente por esse motivo - a aquisição de títulos das mais variadas formas - é que Joaquim dos Anjos avalia a capacidade intelectual de certos doutores:

—Esse Leonardo é mesmo homem de inteligência, Quincas?

-É, Engrácia. Por quê?

-Por que ele então bebe tanto?

—uem sabe lá? Vício, hábito, capricho da sua natureza, desgostos, ninguém sabe! - observou o marido.

-Eu vejo tanto doutor por aí que não bebe.

—Você pensa que todo doutor é inteligente, Engrácia?

-Pensei.

Clara ficou admirada de que a opinião da mãe não fosse exata. Ela também, muito popular e estreita de idéia [sic], admitia que toda a espécie de doutor fosse de sábios e inteligentes (BARRETO, 2011, p. 138).

O questionamento que Joaquim faz a Engrácia, sua esposa, sobre a inteligência de determinados doutores, assim como a configuração assumida por Meneses, retrata um período marcado pela necessidade de autoafirmação pela posse de algum título, e mostra ainda que "é freqüente [sic], entre os brasileiros que se presumem intelectuais, a facilidade com que se alimentam, ao mesmo tempo, de doutrinas dos mais variados matizes e com que sustentam, simultaneamente, as convicções mais díspares." Para sustentar o pedantismo que possuem, "basta que tais doutrinas e convicções se possam impor à imagem por uma roupagem vistosa: palavras bonitas ou argumentos sedutores" (HOLANDA, 1995, p. 155). A crítica de Lima Barreto não é só aos doutores bacharéis, mas também aos doutores das letras, notadamente, os falsos doutores, aqueles sem capacidade intelectual para outorgar-se como tal, ou que sustentam teses falsas, sem fundamentos. Nesse rol, encontram-se os defensores do 
evolucionismo darwiniano, o "cemitério das letras e dos literatos" composto por "cadáveres bem embalsamados" (da Academia Brasileira de Letras), e a fabricação em massa de bacharéis de elite brasileira (SCHWARCZ, 2017). Lima Barreto representa o homem e a vida como são, sem máscaras, sem aparências e com toda a sinceridade que foi capaz de alcançar.

\section{NÃO SOMOS NADA NESSA VIDA}

Em seu Diário Íntimo, Lima Barreto (1956, p. 33) confessa sua pretensão: "No futuro, escreverei a História da Escravidão Negra no Brasil e sua influência na nossa nacionalidade." Ao conhecer a produção literária do escritor, sabe-se que a obra exclusivamente sobre a história da escravidão negra no Brasil não chegou a ser concretizada. De outro modo, pode-se dizer que Lima Barreto conseguiu criar diversas obras e personagens que, sem dúvida, mostram como se deu a formação do caráter nacional, influenciado pela condição do negro escravizado durante quase três séculos. Mostrou de forma representacional, em personagens como Isaías Caminha, Clara dos Anjos e seus condescendentes, que mesmo após a Abolição as marcas da exploração permaneceram visíveis, quando os negros libertos foram jogados à própria sorte, sem o amparo de um projeto que amenizasse o sofrimento e a precariedade de séculos. O processo precisava ser mais profundo:

\footnotetext{
Não bastava alfabetizar o negro ou prepará-lo, intelectualmente, para certos ofícios. Impunha-se prepará-lo para todas as formas sociais de vida organizada, essenciais na sua competição com os brancos por trabalho, por prestígio e por segurança e lhe garantir, além e acima disso, aproveitamento regular de suas aptidões e autonomia para pôr em prática seus desígnios (FERNANDES, 2008, p. 101).
}

Longe desse ideal, ao contrário, foram lançados ao acaso, postos à margem da sociedade e de qualquer benefício social ou amparo legal efetivo. Os "homens livres", sem a devida assistência, dependiam agora do favor, outra forma de servilismo que impossibilitava qualquer ascensão social.

Um exemplo da dependência de favores para o negro, em Clara dos Anjos, pode ser visto em Joaquim dos Anjos. Para sair de Diamantina, sua cidade natal em Minas Gerais, e mudar-se para o Rio de Janeiro, precisou da ajuda de John Herbert Brown, um geólogo que foi seu patrão na cidade mineira. Chegando ao Rio, precisou de mais um favor para conseguir trabalho em um escritório de advocacia. $\mathrm{O}$ doutor lhe concede o emprego, adianta que ele não receberá grande coisa, mas vai adquirir conhecimento para, mais tarde, conseguir algo 
melhor: "Viu bem que o 'doutor' lhe falava a verdade, e toda sua ambição se cifrou em obter um pequeno emprego público que lhe desse direito a aposentadoria e a montepio, para a família que ia fundar" (BARRETO, 2011, p. 17). Joaquim representa o momento histórico em que "o senhor liberta-se do escravo e traz ao seu domínio o assalariado, migrante ou não" (BOSI, 1992, p. 272). O salário que Joaquim receberia do advogado não seria grande coisa e ele sabe por antecipação, mas não pode reclamar, pois o doutor está lhe prestando um favor. Como já observou Schwarz (2012), o favor, como um tipo de tratamento mais atenuante e sutil que a relação escravista, representa uma forma de mediação "quase universal" entre os brasileiros. É esse tipo de mediação que vai determinar os limites da progressão social de Joaquim, domando sua ambição de tornar-se alguém importante.

O papel de Joaquim na narrativa é, sem dúvidas, importante para entender a condição do negro recém-liberto, jogado às margens de uma República que muito prometia e pouco efetivava seus ideais. É notável também a configuração de Dona Engrácia, com seu temperamento "inerte" e "passivo". Se ela era ativa nos trabalhos domésticos, ao mesmo tempo se mostrava incapaz de tomar decisões em momentos de emergência, já que relegava todas as tomadas de decisões ao marido Joaquim. Contudo, entre todos os personagens, nenhum irá perceber de forma tão dura a sua condição e seu papel como Clara dos Anjos, personagem que dá nome ao romance. Essa é, possivelmente, a obra em que Lima Barreto mais trabalhou na construção de um personagem que encarnasse todo o preconceito e agruras de uma sociedade desigual. E Clara possuía todas as características para isso, era mulher, negra e pobre. Essa tríade sentenciava o destino de um indivíduo em meio ao tipo de sociedade que formava o contexto brasileiro entre os séculos XIX e XX.

Clara foi o único filho sobrevivente da família dos Anjos. O narrador a descreve como uma pessoa de natureza "amorfa" e "pastosa". Pesou sobre ela, segundo as convenções da época, a necessidade do casamento. Certa vez Marramaque, padrinho de Clara, foi fazer uma visita ao compadre, quando a afilhada estava servindo-lhe o café ele perguntou: “-Então, minha afilhada, quando se casa? - Nem penso nisso - respondia ela, fazendo um trejeito faceiro" (BARRETO, 2011, p. 24). Se Clara não deu importância à pergunta do padrinho, foi mais atenta quando Lafões pediu permissão a Joaquim para trazer, no dia do aniversário de Clara, um tal de Cassi, mestre de violão e modinha. O que nem todos sabiam é que "o Senhor Cassi Jones, de tão pouca idade, relativamente, contava perto de dez defloramentos e a sedução de muito maior número de senhoras casadas" (BARRETO, 2011, p. 25-26). Em geral, as moças de quem ele tirava proveito eram humildes e de cores variadas, mas o perfil deveria ser o mesmo: incapazes de vencer a influência da sua família, quando necessitasse de 
apoio para livrar-se das grades. Além da proteção incondicional da mãe, ele também contava com a "benevolência secreta de juízes e delegados, que, no íntimo, julgavam absurdo o casamento dele com as suas vítimas, devido à diferença de educação, de nascimento, de cor, de instrução" (BARRETO, 2011, p. 82). Os julgamentos de Cassi não eram feitos segundo a letra fria da lei, pois os juízes e delegados "no íntimo" se condoíam em ter de castigá-lo com tão dura pena, obrigando-o a casar-se com suas vítimas. A compreensão desse problema levou à seguinte afirmação: “As constituições feitas para não serem cumpridas, as leis existentes para serem violadas, tudo em proveito de indivíduos e oligarquias, são fenômenos correntes em toda a história da América do Sul” (HOLANDA, 1995, p. 182). Os malabarismos no exercício da lei, para atender a interesses e fins específicos, são comuns na sociedade brasileira. Tudo isso está gravado em nossa memória e disseminado pela sociedade ao longo da história.

O fato é que Cassi, usando dos mais abomináveis métodos, conseguiu chegar até Clara. Teve o primeiro contato na festa de aniversário dela, por intermédio de Lafões. Orquestrou, juntamente com seus comparsas, a morte de Marramaque, a quem considerava um empecilho; aproveitou-se da miséria de Meneses, dentista de Clara, para estabelecer comunicação e trocar cartas; finalmente, conseguiu seduzir e aproveitar-se da pobre e ingênua mulata, quando penetrou em seu quarto, certa noite, a pretexto de fugir de uma tempestade. Clara não possuía a educação e a orientação necessária, e deixou-se levar pelo desejo. A consequência disso tudo foi uma gravidez indesejada. Agora, ela era mulher, pobre, negra e grávida. Tendo sido abandonada pelo seu algoz, pensou em abortar, mas foi dissuadida por Dona Margarida, uma amiga da família, a não praticar tal ato. Foi, inclusive, Dona Margarida, com sua altivez e imponência de alemã, características destacadas pelo narrador, quem convocou Clara e a mãe a irem à casa de Cassi buscar uma resolução para o problema em questão. Chegando ao destino, foram atendidas por Dona Salustiana. Dona Margarida contou todo o ocorrido e Dona Salustiana limitou-se a perguntar "-Que é que a senhora quer que eu faça?". Clara se antecipou na resposta e, sem saber com quem estava falando, proferiu: “Que se case comigo" (BARRETO, 2011, p. 142). Dona Salustiana, imediatamente, olhou para Clara tomada de "malvadez e indignação" e a chamou de "negra", "gente dessa laia", o que tornaria inadmissível qualquer relação entre a acusada e seu filho, que ela dizia ser neto de um tal Lord Jones, cônsul da Inglaterra em Santa Catarina.

Quando terminou de descarregar todo o seu preconceito violento sobre Clara, tentando livrar a culpa do filho como já fizera outras vezes, Dona Salustiana ainda acrescentou que o erro é das mulheres que aceitam, pois não são obrigadas a nada. Clara ainda se humilhou 
implorando ajoelhada aos pés de Seu Azevedo que a ajudasse, mas este se mostrou impossibilitado. Quando já estavam na rua, depois das dores e da humilhação sofrida, "agora é que tinha a noção exata da sua situação na sociedade" (BARRETO, 2011, p. 143). Após todo o sofrimento, Clara chegou à dolorosa conclusão: “- Mamãe! Mamãe! — Que é minha filha? - Nós não somos nada nesta vida" (BARRETO, 2011, p. 144). O preconceito de Salustiana possui seus fundamentos na visão que o branco tem sobre o negro no final do século XIX e início do século XX. Se o negro não é mais escravo, certamente é descendente. Portanto, para Lima Barreto, escrever sobre sua condição, sobre o contexto no qual estava inserido, através da personagem Clara, é um ato de insubordinação, de não aceitação do lugar que o negro estava inserido.

Tratando de como o negro liberto era visto na sociedade, Fernandes (2008, p. 89) aponta que os brancos "viam no liberto o ex-escravo e tentavam tratá-lo como tal." Em um estudo sobre O negro no mundo dos brancos, Fernandes (1972, p. 31) destaca as contradições do projeto abolicionista, no qual "a reintegração do sistema de relações raciais ficou entregue a processos sociais espontâneos." Foram esses "processos sociais espontâneos", ignorados pelas elites que se revezavam no poder, que deixaram o negro sem assistência e o fizeram sofrer em condições precárias, passando por todo tipo de preconceito. A fala de Clara para a mãe sintetiza as dificuldades que acometem o indivíduo negro e pobre. A segregação e o preconceito se intensificam se este mesmo indivíduo é do sexo feminino, alguém que já carrega consigo, desde o nascimento, o destino de viver em uma sociedade com papéis preestabelecidos. Certa vez, Conceição Evaristo disse que "a nossa escrevivência não pode ser lida como histórias para ninar os da casa-grande e sim para incomodá-los em seus sonos injustos" (EVARISTO, 2007, p. 21). É também nessa perspectiva que se deve entender a narrativa barretiana.

Após esse percurso pela narrativa de Clara dos Anjos, é possível perceber as impressões de Lima Barreto em sua obra, talvez como um elemento "pessoal" que não se limita ao "personalismo", mas aponta:

para uma representação destemida e não-conformista da sociedade em que viveu. Espelho contra espelho (para usar noutro sentido a imagem de Eugênio Gomes) é uma das atitudes básicas desse rebelado que fez da sua mágoa uma investida, não um isolamento (CANDIDO, 1989, p. 50).

Conforme a crítica de Antonio Candido, a peculiaridade de Lima Barreto está em fundir problemas pessoais e sociais, optando, quando possível, pelo viés que depõe sobre as 
duas causas, como, por exemplo: a pobreza como um problema da estrutura da sociedade e o preconceito transposto em forma de angústia, ambos decorrentes das normas e interesses de determinados grupos. Por fim, a escrita de Lima Barreto é um ato de resistência, "um movimento interno ao foco narrativo, uma luz que ilumina o nó inextricável que ata o sujeito ao seu contexto existencial e histórico" (BOSI, 2002, p. 134). Essas são algumas das possíveis interpretações sobre Clara dos Anjos, um romance que apresenta, em seu enredo, questões ainda presentes em nosso tempo.

\section{REFERÊNCIAS}

BARBOSA, Francisco de Assis. A vida de Lima Barreto: 1881-1922. 11 ed. Belo Horizonte: Autêntica, 2017.

BARRETO, Lima. Clara dos Anjos. In: Histórias e Sonhos. 1 ed. Rio de Janeiro: Gianlorenzo Schettino, 1920. p. 142-153.

. Diário íntimo. São Paulo: Brasiliense, 1956.

. Clara dos anjos. 2 ed. São Paulo: Escala, 2011.

BOSI, Alfredo. Dialética da colonização. São Paulo: Companhia das Letras, 1992.

. Narrativa e Resistência. In: Literatura e resistência. São Paulo: Companhia das Letras, 2002. p. 118-135.

CANDIDO, Antonio. Os olhos, a barca e o espelho. In: A educação pela noite e outros ensaios. São Paulo: Ática, 1989. p. 39-50.

Literatura e sociedade. 9 ed. Rio de Janeiro: Ouro Sobre Azul, 2006.

CARVALHO, José Murilo de. Os bestializados: o Rio de Janeiro e a República que não foi. 3 ed. São Paulo: Companhia das Letras, 1987.

DAMATTA, Roberto. Sabe com quem está falando? Um ensaio sobre a distinção entre pessoa e indivíduo no Brasil. In: Carnavais, malandros e heróis: para uma sociologia do dilema brasileiro. 6 ed. Rio de Janeiro: Rocco, 1997. p. 179-248.

EVARISTO, Conceição. Da grafia-desenho de minha mãe, um dos lugares de nascimento de minha escrita. In: ALEXANDRE, Marcos Antônio. (Org.). Representações performáticas brasileiras: teorias, práticas e suas interfaces. Belo Horizonte: Mazza Edições, 2007. p. 1621.

FERNANDES, Florestan. O negro no mundo dos brancos. São Paulo: Difusão Européia do Livro, 1972. 
. A integração do negro na sociedade de classes. 5 ed. São Paulo: Globo, 2008.

FREIRE, Manoel. A motivação autobiográfica em Lima Barreto. Manuscrítica, Revista de crítica genética, São Paulo, n. 26, p. 86-96, 2014. Disponível em: http://www.revistas.fflch.usp.br/manuscritica/article/view/2096/1990. Acesso em: 25 set. 2020.

HOLANDA, Sérgio Buarque de. Raízes do Brasil. 26 ed. São Paulo: Companhia das Letras, 1995.

LINS, Osman. Lima Barreto e o espaço romanesco. São Paulo: Ática, 1976.

SCHWARCZ, Lilia Moritz. Lima Barreto: triste visionário. São Paulo: Companhia das Letras, 2017.

SCHWARZ, Roberto. As idéias fora do lugar. In: Ao vencedor, as batatas: forma literária e processo social nos inícios do romance brasileiro. 6 ed. São Paulo: Duas Cidades; Ed. 34, 2012. p. 10-31.

SEVCENKO, Nicolau. Literatura como Missão: tensões sociais e criação cultural na Primeira República. São Paulo: Brasiliense, 1995. 